\title{
THE NEW URBAN AGENDA, THE INTERNATIONAL CIRCULATION OF URBAN POLICIES AND CHALLENGES OF A HUMANE URBANISM IN THE GLOBAL SOUTH
}

\author{
Mahesti Okitasari \\ United Nations University Institute for the Advanced Study of Sustainability \\ Japan \\ e-mail: okitasari@unu.edu
}

\begin{abstract}
In many ways international circulation of urban policies is indispensable to the spread of planning regimes. Contemporary cities in the Global South are sensitive to global, local, relational and territorial geographies, flows and fixity and the increasingly diverse stakeholders. The gradual integration of major international references associated with sustainable urbanism into local interventions combining social, economic and environmental prevention exemplifies the pervasiveness of global approaches. On the other hand, the production of cities is seasoned by the complex state-society relations as the planning practice struggles to respond to the hegemonic urban planning that are time, scale and geographically specific.

Building on this background, this paper revisits the notion of the New Urban Agenda within the international circulation of urban policies, practices and models from the standpoint of cities in the Global South. It examines the push and pull in the global process for the inclusion of initiatives that respond to the needs of Southern cities. This paper sets to explore the New Urban Agenda within the current borrowing, adaptation and hybridization of planning practices and how it can contribute to the debate of localizing the Agenda towards humane urban policies fitting to the needs of the people. This paper identifies impediments to the attainment of the New Urban Agenda as it is circulated, sets to be adapted and taken up, and mutates. This paper contributes to two conversations within planning academics on the implication of the New Urban Agenda: to the international circulation of urban policies and the making of contemporary cities in the Global South and to the struggle facing cities towards a humane urbanism.
\end{abstract}

Keywords: the new urban agenda, urban policy circulation, humane urbanism 


\section{INTRODUCTION}

The turnover of the millennium saw the world's urban population surpassed the fifty percent mark (54 percent in 2014) and started to pivot toward more urban than rural. In 2050, global urbanization is expected to reach two-thirds of the world's population. Close to 90 percent of the population increase is expected to take place in Asia and Africa (UNDESA, Population Division, 2014). Among them, the number of highly urbanized countries is projected to continue increasing, including the area-bound small island developing countries. With the global urbanization continues its upward stretching, creating a mutually reinforcing relationship between urbanization and development as a parallel vehicle for sustainable development is inevitable. To this end, decision makers, planners, citizens and other stakeholders involved must take into account strengths and vulnerabilities of urban, its linkages to rural areas, its culture and geographical context, which call for humane responses.

Cities with their stronger administrative and economic power as compared to rural areas are better in collectively anticipating risks and building resilience against the aggregation of people, infrastructure, natural and climate cause. Yet still, cities require inclusive long and short term planning, design, financing, legal and regulatory frameworks. On this front, realizing a well-planned and managed urbanization through sound and enforceable legal frameworks calls for an evolution on how cities approach urbanization (Clos, 2016). Evolution is needed as the industrialized approach of urbanization through the over-reliance on the industrialized form of urban sprawl fails to properly address the rapid urbanization in developing countries (Clos, 2016).

\section{THEORY / METHODS}

For decades, inclusive planning has been referred as the panacea to combat the various challenges of urbanization. What being less addressed is that aiming for inclusive planning requires cities to address the fragility and paradox of urbanization and the never ending conflicts within the planning practice. Planning is notably prone to conflicts, particularly in a quest to balance its economic, social and environmental aspects (Campbell, 1996). Conflicts take place as planning operates on highly situational environment where there is no replicable model without contextualization of local setup (McCann, 2011). External factors also influence the way planning is conducted, creating additional sources of conflict. Among many, the influence of international agenda is indispensable to the production of urban policies (McCann, 2011; Peck and Theodore, 2010). The international mobility of urban policies provides opportunities for better planning system and products, but it also creates struggles to counter imported planning practices which do not always conform to the complex state-citizen relations within inherited regimes (Miraftab, 2009).

Rapidly growing cities in the Global South are sensitive to the global and regional policy mobility due to high mobility of goods, people and finance, bringing about relational changes of borrowed concepts. Policy development is no longer 
conducted within bounded national frameworks (Cochrane and Ward, 2012) nor positioned within nested scalar hierarchies (Bulkeley, 2005). In a planning system operated through a rational evidence-based policy, cities in the South borrow and reuse successfully perceived public policies developed in the North (Peck and Theodore, 2012). Despite acknowledging that a direct policy transfer is practically improbable (Cochrane, 2011; Theodore and Peck, 2012), not much research are devoted to explore the complex processes of North-South policy translation. Cities in the South remain as major recipients of international policy mobility. New global policies continue being mainstreamed without proper evaluation and adjustment to fit the existing planning system of the South. Planning practices in many Southern cities, thus, struggle to respond to the hegemonic urban planning which does not always respond to their needs nor fit their basic values.

Against this background, this paper focuses on the current conversations within academics in addressing the implication of international policy mobility to cities. This paper takes its perspective from the literature on policy mobility and humane urbanism. It tries to understand the ramification of the New Urban Agenda towards domestic planning challenges facing the cities in the Global South. In order to properly understand the influence and the extent of the New Urban Agenda, this paper attempts to pinpoint the positioning of the New Urban Agenda within the context of current development and planning paradigm.

This paper is divided into four sections. Each section centers on key contexts pertinent to understanding the notion of international policy mobility operating through international agenda. Section one gives literature review on the international circulation of urban policies in regard to changing development paradigms of planning. This section offers a background on the positioning of the New Urban Agenda against the major developmental paradigms of cities and urban planning. Section two provides a relational background of the Habitat agendas through historical analysis of divergent priorities of the New Urban Agenda and its predecessors. It subsequently addresses several thematic issues the Agenda has offered as a response to the emergence of new urban development paradigms. Section three examines gaps and opportunities for Southern cities under the New Urban Agenda. This section examines in detail the New Urban Agenda from the perspective of humane urbanisms as well as the practicality of its implementation. The final section of the paper draws directions of future planning discussion in setting up a timely, geographically and culturally bound humane urbanism for cities in the Global South following the implementation of the New Urban Agenda.

\section{RESULTS AND DISCUSSION}

\section{International Circulation of Urban Policy}

Since the establishment of modern planning, the gradual integration of global approaches into local interventions over the years exemplifies the importance of decision makers to take into account major international references in the production of local plans. The issue of the international circulation of urban policies takes 
precedent over indigenous and local planning in the global and regional discussion with the adoption of the 2030 Agenda and the New Urban Agenda. Once again, the global stakeholders set a global development trajectory to be implemented at the national, sub-national and local levels. These two global agendas aim to promote knowledge platforms to enable exchanging and sharing successful strategies and initiatives. The so called "successful policy models" closely correspond to the goals of the two global agendas are expected to move across borders and gain political importance among policymakers.

While the overall idea of integrating global approaches into local plans has been pushed forward for decades, there were few discussions among global decision makers on the implication of exploiting globally accepted policy models and regimes originated from different places and intended for different purposes. There was lack of rigorous global debate in regard to the causal impact of possible alterations of these circulated policies and initiatives. Our observation across global governance literature found that the globalism enthusiasm has overlooked the influence of new global agendas to the international circulation of urban policy. Unfortunately, a similar trend has taken place within planning research. Planning research devoted to conceptualize, characterize and examine the international circulation of urban policy in prior to the New Urban Agenda and the 2030 Agenda have been low. To make it worst, despite contemporary writing crosscutting the field of urban, political and economic geographies have framed the global agendas as 'policy assemblages, mobility and mutations' (Temenos and McCann, 2013), which entail more conceptual understanding, the knowledge sharing platform circulating among the stakeholders during the global process was treated as the abstract notion and political logic.

This negligence is worrisome considering there is no circulation of policy models everywhere without alterations which make them strangely familiar to the original context (Temenos and McCann, 2013). As globalism and neoliberalism pressures mount over cities, it is most important that new planning and design strategies embedded in the new global agendas to be examined to fit the geographies they constitute and reflect local movements of policies in order to avoid local needs and values being left behind.

While there was low interest to link literature on the international circulation of urban policy and the global agendas, research have progressed on the practical and conceptual issues of international circulation of urban policy. Recently, careful attention has been given to the overlapping spaces of policy making, taking into account the clusters around developmental paradigms, including their networks, priorities and conflicts. This reinforced the discussion to approach the issue of policy mobility differently. Instead of examining how strategies and initiatives could be successfully transferred, research looked into particular local sets of political, social and cultural conditions (bottom layer) (Cochrane, 2011) and circulatory capacities of centers of calculation among decision makers (upper layer) (Freeman, 2012; Roy, 2012).

Ideally similar considerations should be given at all levels by all stakeholders involved prior to adopting a set of goals and targets related to the new global agendas. With the broad coverage of global goal and targets, it becomes 
necessary to examine to what extent these new goals and targets are compatible with national and local directives across and within silos. Considering the implication of the agendas for planning, if they are not carefully redefined and incorporated into a broader understanding of socioeconomic and political conflicts, the agendas can be both useful and problematic organizing principles for national and local planning. To this end, considering the fleeting characters of urban developmental paradigm, approaching and translating the new global agendas with a cautious and critical eye will benefit cities, governments, planners and citizen alike.

In general, there was relatively less controversy over the New Urban Agenda's main provision. The negotiations building up to the final document were less antagonistic than the 2030 Agenda or the Paris Agreement. The document adhered to the various callings of most updated urban initiatives including, inter alia, polycentric growth (para. 95), compact cities (para. 51; 52), sprawl prevention (para. 52), mixed-use streetscapes (para. 51) and transit-oriented development (para. 114). The New Urban Agenda also cemented the concept of urban governance (para. 15 ; 85-92). Whether some concerns were raised or not as these initiatives largely came from the industrialized North we would have never known as there was no controversy on that front. But, within the context of international circulation of urban policy, there are three takeaways from where we can examine what the New Urban Agenda entails; developmental paradigm and the right to development, sustainability conflicts and geographies of policy.

\section{Developmental Paradigm of Cities and Urban Planning}

The current urban policymaking process is consistently formulated with explicit references to global contexts as a result of constant pressures to decades of structural reconstruction. Policy networks with extensive global outreach are used as the main infrastructure of exporting and importing developmental paradigms underlying the production of urban policies. In the case of urban policies in major Southern cities, policies and priorities are exported through consultation with international experts and formulated through exchanges among professional and political networks. It is equally important that taking such an approach make it necessary for cities to rethink how to conceptualize some of the taken-for-granted measures and tools. Whatever the outreach of globalized urban policies to the local policymaking, it cannot be understood just as a developmental model, but more as contextual knowledge and ideological hegemony.

Governance models and policy initiatives do not transfer as fast as what we envision. Policy assemblages, mobility and mutations take time to set in their new place, even more with lack of available resources. On the other hand, developmental paradigms of cities and urban planning from the industrialized North change faster than the adaptive capacity of recipient cities in the Global South. As a consequence, planning and design strategies are often transmitted past after their period of time, thus operate under a different social political environment than to their original version. If planning and design strategies are products of the socio-political environment built over time and carrying the particular interests involved (Ward, 2006; McCann, 2008; Peck and Theodore, 2010), ignoring the time gaps and the 
differing context of social issues as cities import certain strategies will create a danger of undermining said strategies.

How we perceive cities, or rather how planners try to understand cities through planning theories and approach, continuously change. While planning theories are high in numbers, they can be grouped into two streams, physical or contextual and process-based. Planning in the first half of the $20^{\text {th }}$ century was largely physical in approach. Planners at that time moved from seeing the city as a living organism (Howard, 1898) to psycho-geography of seeing unitary urbanism in which the behavior of cities reflects the emotions and behavior of their inhabitants (Debord, 1955). The second half of the $20^{\text {th }}$ century took the perspective of process based approach. Planners tried to further integrate behavior through the understanding of the social process, e.g. community development, advocacy planning (Davidoff, 1965). Planning approach also started to look at broader structuring forces through the use of agencies and moved away from 'context' to 'process', e.g. communicative planning and collaborative planning (Huxham, 1996; Healey, 1997). Culture as an organizing concept and framework of planning was also cited as the new driver of planning (see Lefebvre, 1974). Recently, insurgencies offered a new driver for planning, particularly among cities in the Global South (Miraftab, 2009).

Planning theories aside, policy planning practices continue recycling the use of planning tools coming from the US, UK and Europe. On one side, we have strategic spatial plans and comprehensive plans, which are largely influenced by US ideas on the rational policy process. On another side, there are structural plans, policy principles and regulatory norms following the influence of the synoptic approach in the British Town Planning. Paralleling a growing planning practice literature and growing recognition of the importance of interpersonal relations, planning through advocacy has also gained grounds (Sabatier and Jenkins-Smith, 1988).

On the basis of unprecedented changes on urban challenges as well as the development of planning practices, the New Urban Agenda is set to promote the promise of a paradigm shift in the way we plan, develop and manage urban development (Quito Declaration on Cities for All, para. 3). However, the New Urban Agenda did not explicitly define the developmental paradigm shift and instead offered broad and vague contexts. At least four main developmental shifts were implied in the New Urban Agenda; the linkages between environment and development, the practice of just sustainability, the challenge toward growthdependence paradigm and the incorporation of social justice into planning. None of these concepts is particularly a novel approach, yet their applicability, effectiveness and impacts in urban planning and management remain challenging for planners. While these concepts are not new nor radical within the planning discussion, the New Urban Agenda was the first global agenda to provide the political venue and bring issues of cities in the international development forum.

Issues of developmental paradigm and right to growth and development always create push and pull between the North and the South. Despite being only a political victory, the Global South through G77 successfully attached the term 'right to development' into the final document of the New Urban Agenda (para.12). The 
right to development has been the focus of theoretical debates for decades (M'baye, 1972; Dupuy, 1980). It represented a dialectic of the sovereign equality of states (Dupuy, 1980). The global dynamic behind the right to development is somewhat more representative of the different viewpoints between the North and South in term of the human right, the structure of international economic relations and the distribution of power in international relations. In almost all global negotiations, participants from the South always express the need for political and economic transformation in international relations than seek for concessional resources (Barsh, 1991). The North, on the other hand, seeks for the fulfillment of basic human needs as a part of capitalism moderated by the redistribution of income by the state (A/RES/41/120, supra note, art. 8.1). While keeping up with this North-South conflict, the inclusion of the right to development in the New Urban Agenda failed to offer any practical application. It lacked workable programs with direct relations to address the struggles behind the right to development.

\section{The New Urban Agenda and the Conflicts of Sustainability}

The New Urban Agenda arguably put planning at the center of actions to realize its targets of inclusive and sustainable cities. Explicitly, the New Urban Agenda resolved to leave no one behind, to leverage sustainable and inclusive urban economies and environmental sustainability (para.14). By doing so, the New Urban Agenda echoed a similar call dictated in the 2030 Agenda (target 11.3). The New Urban Agendas also synthesized various development paradigms to make cities sustainable through planning measures and tools. It underlined the interconnection between the planning system and governance, and their fundamental issues of realizing sustainability. By expressing explicitly planning challenges for sustainable cities, the New Urban Agenda pointed various conflicts and capacity issues within planning agencies and stakeholders in regard to sustainability. It revived the discussion of conflicts between environmental sustainability and socioeconomic justice within the context of inclusive and sustainable cities.

The struggles behind ensuring sustainability are the examples of classic cities conflicts. Planners and decision makers are always in a constant struggle of making decisions about where they stand on protecting the green city, promoting the economically growing city and advocating social justice (Campbell, 1996). The holistic ways the sustainable development concept has offered are yet to suffice and often to be given to avoid those conflicts. Sustainability conflicts are far embedded into the historic core of planning, a genuine clash of interest "man vs nature" (Campbell. 1996). Consequently, taking into account the idealism of planning, translating across discipline and working across silos while useful for the implementation are not enough to holistically remove these conflicts. In most cases, the practices of working across silos and discipline put more emphasis on the strength of personal relations and less about planning as a tool and a complex system. Nevertheless, redefining the sustainability conflicts can sharpen the debate and open up new channels of ideas.

The New Urban Agenda framed the needs of radical change in planning as a tool to shift the attention back to the city as a political entity in the forefront of 
planning struggles in realizing sustainability. The New Urban Agenda offered broad points on how cities should deal with the ongoing conflict between pillars of sustainability as well as conflicts within governance. On this front, the current trends among planning literature are split among green economy, humane urbanism, just sustainability and insurgent planning. The first one deals with the conflict between the economy and the environment; the second one is between social and the environment; the third argues on the basis of economic and social aspects; and the last is on citizen governance. These conflicts, while getting more complex than those in the 1990s, remain within the same line of criticisms (see Campbell, 1996).

On the topic of sustainability conflicts, the use of the word "transformative" in the New Urban Agenda pointed heavily to the crosscut between environmental sustainability and just society (para. 58) although its stance between the goals of environmental protection and social justice was ambivalent. The Agenda directed attention toward issues of improving quality of life and wellbeing, meeting the needs of intra-generational and intergenerational equity while living within ecosystem limits. By giving emphasis on these issues, it acknowledged the needs for critical and coherent planning tools and techniques available for justice and equity in terms of process, procedure and outcome. However, the New Urban Agenda did not offer explanation to address the compatibility concern between the existing environmental sustainability measures and social justice issues.

The New Urban Agenda failed to give proper attention to the insurgent planning issue and its conflicts. While the Agenda managed for the first time to include the word 'cities for all', it did not provide directives on how to accommodate insurgent space for the right of inhabitant. It was vague on the conflict between economic growth and economic justice. In the end, the economy-social conflict was lost in the overall tone of the Agenda despite the greater interest it gave to achieving contemporary societies and economies which respects its environment.

\section{From the Habitat I to the New Urban Agenda}

The international circulation of housing policy was first institutionalized at the global level with the resolution adopted by the United Nations General Assembly (UNGA) following the first Habitat conference on Human Settlements in Vancouver, Canada in 1976. Its outcome document (A/RES/32/162) endorsed the international arrangements for international cooperation in the field of human settlements. This resolution marked the starting point for global actors to formally register basic problems experienced in many cities with regard to the rapid urbanization. Its promotion of international cooperation opened windows to escalate the mobility of emerging concepts between the North and South. In particular, the document promoted the international policy mobility to developing countries through technical cooperation in policy formulation, management and institutional improvement (A/RES/32/162, part I art. e). The newly formed UN Habitat was tasked as the main global agent to develop and promote policy objectives and priorities as formulated in the Vancouver Action Plan. 
From the perspective of the right to development, the outcome document of Habitat I was considered progressive as it recognized the establishment of a just and equitable world economic order through changes in various area affecting developing countries (A/RES/32/162, preamble, art. c.). The evaluation of its practical implementation on the right to development and the impact of policy mobility, however, was never appeared anywhere in UN reports and papers. Leading to the second Habitat conference in Istanbul, views on international development were still predominantly driven by economic growth as the answer to poverty and urbanization, and sprawl as the driver of poverty and inequity.

The word "right to development" reappeared in the Habitat Agenda (Chapter I, Preamble, art. 4) along with two themes of equal global importance; adequate shelter for all and sustainable human settlements development in an urbanizing world. The key point of the Istanbul Habitat Conference was the recognition of local government authorities, academics and other nongovernmental actors in the pursuit of securing global panacea to urbanization and lack of adequate housing for all. However, as its predecessor, the Habitat Agenda failed to set out binding means to structurally address issues it has recognized. Even as urban policies and initiatives gradually moved to the center of global agendas, issues related to urbanization and inequality have continued increasing.

Habitat conferences, their processes and products without a doubt are the cornerstone of UN Habitat and the UN in the field of housing and basic services and, to certain extent, contribute greatly to the global development. Since 1976, multiple new concepts related to cities and housing have been transferred, reproduced and recirculated, yet poverty and deprivation remained. Policy mobility within the Habitat agendas, thus, resembled a policy conversation more instead of a changing paradigm movement.

The substantive debates preceding the New Urban Agenda have identified many relevant issues to be covered during the Habitat III process. While the 22 issue papers tried to reflect ongoing global and thematic perspectives, these papers offered less about what has come before. None of these issue papers discussed the achievement and shortcomings of the Habitat Agenda. No reference has been made in regard to commitments that were made at the 1996 Habitat Summit. Regardless the unbinding nature of the agreement signed by member states in Istanbul in 1996, lack of reviews on its achievements could render the Habitat III process and its implementation in doubt.

Critical conceptualizations of the New Urban Agenda left behind not only the commitments made during the Habitat II process, but also several thematic perspectives that have been at the heart of the Habitat Agenda. Instead, politically, it demonstrated a celebratory embrace of the current hegemonic policy models and left behind the considered outdated approaches. Among many thematic issues, three issues deserved to be addressed in relation to the scope and scale they affect and are influenced by the international mobility of urban policies are: rural urban linkages, the right to adequate housing and good governance. These three issues were forefront in the Habitat Agenda, but were watered down in the New Urban Agenda despite their importance to today's urban discussion. 


\section{Rural Urban Linkages}

Research on global development have focused more on cities as the last decade saw the declining interest on rural urban linkages that once had been one of the Habitat Agenda core promises. With its urban exclusiveness, the New Urban Agenda no longer put a balanced rural and urban development in its forefront battle to provide humane cities. While the final document included rural urban linkages, it failed to respond to the commitment made in the Habitat Agenda. Instead, the New Urban Agenda saw rural urban linkages as "territorial systems that integrate urban and rural functions" (para. 43) and grouped them with "supply and value chains" (para 62), and "to fill the social and economic gaps" (para. 123). Also related to the discussion of rural urban linkages were, inter alia, sustainable transport and mobility (para. 44; 100), water resource and management (para. 63), trade links, sustainable consumption and production (para. 83; 109) and infrastructure to stimulate sustainable economic productivity, promoting partnerships (para. 84).

The inclusion of territorial approach is a response from the New Urban Agenda to the emergence of the territorial development paradigm for rural development, pioneered in Latin America and Southern Europe. Territorial approach entails spatially accented but holistic models, including policy and regulatory reforms, institutional models for cost-effective provision of business, strategies related to diversification of economic activities, improved market links, economic and social infrastructure as well as roles of civic society. While the New Urban Agenda included the spatial strategies such as mobility and trade links, it offered less than the balanced rural urban development proposed by the Habitat Agenda. By taking out the quest for a balanced rural urban development, territorial strategy is propounded ideally for not clearly urban but not deep rural (Barsh, 1999). Yet again, in case of deep rural areas this territorial interaction tries to conceptually solve a rather artificial problem as there seems to be the same conflation between activities and place that has been criticised in the urban bias debate (Karshenas, 1997). Thus, in the course of exporting this territorial approach, its adoption to rural urban development should be carefully adjusted to the economic, social, and cultural situation applicable to the area.

\section{The Right to Adequate Housing}

Not only the issue papers preceding the Habitat III process completely abandoned the human rights approach to adequate housing (Schechla, 2015), the New Urban Agenda cited the right to adequate housing three times only, fewer than the 61 times it appeared in the Habitat Agenda. In turn, the document made concessions to include terms related to better urban life, such as adequate standard of living, equal rights and opportunities, public service, density and infrastructure. Regardless these concessions, the New Urban Agenda, by far, neglected the hard fought development of housing as a right that has taken place since 1996.

By broadening the housing context into an urban agenda, the strength of the New Urban Agenda in the housing sector depends on whether or not it successfully provides new ways to channel housing investments in the service of people and 
sustainable urbanization without forsaking people's right to adequate housing. To this end, the document did not offer much other than promising to provide equal access to public goods and services (para. 10; 87), to strengthen the spatial relationship between the urban fabric and the surrounding functional areas (para. 26) and to ensure that infrastructure is part of integrated urban and territorial development plan, including housing and mobility (para. 105).

\section{Good Governance}

The Habitat Agenda was applauded by many as one of the most progressive UN global agendas as it included progressive issues related to human right and equality without having to be trapped in the North-South development conflict. Beside the right to housing, the inclusion of local authorities as major partners for development was considered a breakthrough in the global process dominated by international organization and national governments. However, the New Urban Agenda's position on the issue of good governance was considerably less progressive. While one of the issue papers specifically addressed urban governance, it did not elaborate the principle of local democratic rule established in the Habitat Agenda, nor its policy mobility and practice. The urban governance issue paper failed to specify the recent movement related to local governance, such as the right to the city, the insurgent of democratic citizenship and radical planning.

The roles of local government and communities were included in the final outcome document of the New Urban Agenda. The role of local governments on development has become more specific than it was in the Habitat Agenda, putting local governments to be of equal importance to those of national and regional. The inclusion of local communities is also particularly welcoming. Habitat International Coalition (HIC) and United Cities and Local Government (UCLG) were credited in pushing forward the argument that the New Urban Agenda as a solution to the urbanization issues, however technically sound and well-financed, would be rendered unsustainable without the support and ownership of the communities in which it would be implemented (Schechla, 2015).

On a critical note, despite the acknowledgement of local government and communities in the urban process, the New Urban Agenda remained vague on defining good governance and overly lenient on institutionalising participatory urban development. The document provided several starting points, such as acknowledging contributions of local governments of equal importance to civil society and other stakeholders (para. 12), and broadening inclusive democratic platforms that allow meaningful participation in decision-making, planning, and follow-up processes for all (para. 35). The document, however, avoided pushing for a local democratic rule and instead conceded for political participation as appropriate (para. 13). Consequently, the document fell short in making sufficient references to the role of local government and communities as the key agents in the construction of democratic legitimacy at local level. 


\section{The New Urban Agenda, Cities in the Global South and Humane Urbanism: the Practicality}

As the New Urban Agenda moves away from housing issues to city issues, it is particularly important for cities in the Global South to formulate an inclusive definition and translation of the Agenda. In this neoliberal hegemonic economic model, Southern cities face the expanded notions of politics and citizenship, making their state and civil society relations more challenging. Within this new rejection of the binary constructs of formal-informal, cities must be understood as relational nodes, constituted by the flows of capital, resource, especially by what we refer as "hot" policy ideas. While cities in general are prone to the global circulation of policies, contemporary cities in the Global South are even more sensitive to global territorial geographies, flows and fixity of global relational conceptualization of place.

Cities in the Global South are flexible to change. As stakeholders import development models, these models shape the production of cities. The New Urban Agenda opens a Pandora box of strengthening neoliberal hegemony. In many ways, the New Urban Agenda could be used as tools to over generalize things and discard the specificity of space. Therefore, it is pertinent to discuss the mobility of urban policies, which undeniably had shaped and is reshaping the production and reproduction of cities. It is also important for stakeholders from the South to fully understand the gaps and opportunities offered by the New Urban Agenda through the international circulation of urban policy in order to fully realize the city they want.

Implementation is crucial in the course of fulfilling the New Urban Agenda in the wake of humanitarian crisis we are in. Positive progresses were made during the course of Habitat Agenda, yet gaps between the Agenda and its implementation to realize a humane urbanism keep getting wider. The New Urban Agenda will need to factor many aspects in the design of its implementing strategies to avoid falling into a similar trap. Achieving the New Urban Agenda and realizing its commitments require recognition of economic, social and environmental challenges and opportunities in urban areas. Furthermore, for many Southern cities, the success of the New Urban Agenda demands a recognition of the impact of inequality taking place in their localities. Inequality is no longer just a human right issue, but it becomes a humanitarian emergency due to its severity. Following this section this paper attempt to further elaborate gaps and opportunities for the implementation of the New Urban Agenda.

\section{Localizing the New Urban Agenda: Gaps and Opportunities for the Implementation}

Cities have the capacity of providing something for everybody only when they are created by everyone (Jacobs, 1961). However, for far too long, local governments and communities have been subdued in the global debates and have been demoted as mere implementers of policies made at the higher levels. The practicality of the neoliberalism hegemonic model works to give more power to the powerful instead 
to those who need it the most. In the urban sphere, local actors are the needy and the global and national actors more often than not act as the powerful ones. As the New Urban Agenda ensures the involvement of cities in its implementation and follow-up review, local actors have to clinch all available opportunities to be active players in the planning process and implementation. Local actors, in particular local governments, are well placed to identify gaps and opportunities in their localities. Depending on the resource, including finance, data, technology and personnel, and supports available, local actors have the potential to harness the local culture and values for development.

Given the importance of local actors in making desired development happen on the ground, achieving sustainable urban development as envisioned in the New Urban Agenda will require them to have a say in the decision that affects their localities. In order to accomplish this, however, local actors need legal and institutional framework to do so effectively. Contributions from local academic experts and practitioners should be encouraged and sought more than international experts. The sustainability of any top-down solution should be limited to generate local ownership of the New Urban Agenda.

Avenues allowing local actors to fully utilize the use of planning to manage growth and inequality are essential to ensure the implementation success of the New Urban Agenda. Localization is needed for not only the New Urban Agenda but also the overall planning process. The advantage of adopting a localizing planning process is that it allows local actors to consider cities in their broader territorial context instead of as a mere spatial part of national territories. It also allows cities to screen unwanted externalities generated by the mobility of international urban policies. Local governments may have to consider the functionality of imported urban policies in their local context, or how emergence international urban policies relates to the needs of their localities. However, those are not tasks that cities can carry out alone. The occurrence of localizing planning process depends whether the national urban policies will have enough flexibility to respond to differing urban realities and localities. On this front, legal and fiscal decentralization will continue being the main drivers alongside strong horizontal and vertical collaborative mechanisms.

Decentralization brings local actors a unique position in multiple ways. In many instances, decentralization is compatible with the emergence of insurgent planning on everyday practices of policy making as it provides chances for local actors to play important roles in the decision making. Decentralization offers avenues for planning professional and planning process to break their roots from the colonialism. For localization to take place in the planning process, planning itself needs to be more accessible to people. Instead of acting as the recipient for the new planning models introduced at the global level, local actors should push for the international community to engage with local actors in new, more effective ways. By doing so, the adopted urban policies will be able to represent the local knowledge, values and concerns. Thus, creating planning models and strategies based on the needs of localities.

On the other hand, local actors should avoid dropping the citizen participation into the trap of neoliberal governance where whenever possible, 
hegemonic power is pursued through perceptions of inclusion (Miraftab, 2009). The practices of international development agencies in defining good governance through community participation should be examined carefully. Such routinization of community participation which depoliticizes the struggle of localities and extends state control within society through the status quo between state-society should be avoided. Hegemonic practices which mandated local participation in decision making process through local government, for example, weaken the power of the communities.

On the issue of participation, the New Urban Agenda used popular terms to pair with participation, such as inclusive. However, the document failed to mention of how this inclusive participation will translate into action on the ground, particularly when it relates to the urban poor. While acknowledging the dysfunctional way issues of poverty, migration and land use interlink with urban land market and policies to systematically marginalize the urban poor, the New Urban Agenda did not explicitly lay out effective alternative to deal with inadequate, unsafe housing, infrastructure and basic service. The co-production of housing and cities in the New Urban Agenda has yet directly promoted the involvement of urban poor, surprisingly, considering the debate surrounding the issue of informality during the Habitat III process.

In the end, the New Urban Agenda presented a seemingly never ending conundrum of informality, participation and right to the cities. With the hard fought term right to cities included in the final outcome document, cities and the proponent of those ideas should not just stop there. As local actors harness their networks to develop their participation in the development and planning process, they should also open up the conversation among themselves to set the ground for shifting from the inclusion of participation to self-determination. Right to cities and right to selfdevelopment are interlinked. The attainment of the first one cannot be achieved without the fulfillment of the latter.

\section{CONCLUSIONS}

\section{Looking Back and Moving Forward}

Earlier, this paper tried to elaborate the notion of the New Urban Agenda as one of the global driver influencing the development paradigm as cities in the South continue their struggles to create humane cities. By all means, the New Urban Agenda left behind many issues pertinent to the development of cities in the Global South, arguably so due to limitation of the document. Development issues on specific area, such as islands and land locked, have been limited and often grouped to be addressed under threats of climate change. In practicality, the New Urban Agenda is a document full of big concepts without a clear guidance on how to implement said concepts. Particularly concerning is its lack of follow up on issues related to Southern cities, burdened with gaps and opportunities of informality, distributional inequality and procedural injustice. 
The pervasiveness of Western planning ideals over the subaltern conceptualization of cities and planning is visible across the New Urban Agenda. Nevertheless, hard fought terms generated from the emergence of planning models from the South are scattered across the document. A small win for a bigger step to understand Southern cities by their own rules of the game instead of the accepted planning prescriptions generated from the North. How the New Urban Agenda creates opportunities and other struggles for resistance will now depend on how cities try to localize and implement the Agenda.

In the long run, the follow-up review of the New Urban Agenda requires all actors involved, particularly from cities, to locate politicized historical memory at the very heart of its implementation practices. Such historical consciousness helps cities to understand and localize their policies to fit their localities. It is also beneficial for cities to develop their own version of humane urbanism. By valuing histories of communities and their participation's struggle as significant knowledge, cities can generate their own emancipatory methodology to better adapt to neoliberal pressures coming from the Global North in the form of emerging urban policies.

\section{ACKNOWLEDGEMENT}

The preparation of this paper is funded by the Japan Society for Promotion of Science (JSPS) fellowship.

\section{REFERENCES}

Adell, G. (1999), Theories and models of the peri-urban interface: A changing conceptual landscape (draft for discussion), Strategic environmental Planning and Management for the Peri-urban Interface, University College London.

Barsh, R.L. (1991), The right to development as a human right: Result of the Global Consultation, Human Rights Quarterly, 13(August), 322-338, Johns Hopkins University Press.

Bulkeley, H. (2005), Reconfiguring environmental governance: Towards a politics of scales and networks, Political Geography, 24, 875-902.

Campbell, S. (1996), Green cities, growing cities, just cities?: Urban planning and the contradictions of sustainable development, American Planning Association, Journal of the American Planning Association, 62(3), 296-312, ProQuest Central.

Clos, J. (2016), The opportunity to build tomorrow's cities, World Economic Forum. Cochrane, A. (2011), "Making up urban policies: The role of global institutions", in G. Bridge and Watson, S. (eds), The New Blackwell Companion to the City, 738-746, Blackwell, Oxford.

Cochrane, A. and Ward, K. (eds) (2012), Theme issue: Researching policy mobilities: Reflections on method, Environment and Planning A, 44(1), 1-19. 
Davidoff, P. (1965), Advocacy and pluralism in planning, Journal of the American Institute of Planners, 31(4), 331-338.

Debord, G-E. (1955), Introduction to a critique of urban geography, Les Lèvres Nues, 6 (September 1955).

Dupuy, R-J. (1980), The Right to Development at the International Level, Springer Netherlands

Healey, P. (1997), Collaborative planning: Shaping places in fragmented societies, Macmillan, London.

Howard, E. (1898), Garden cities of to-morrow, Swan Sonnenschein \& Co., London.

Huxham, C. (1996), "Advantage or inertia: Making collaboration work," in R. Paton, G. Clark, G. Jones and P. Quintas (eds), The new management reader, 238-254, Routledge, London.

Jacobs, J. (1961), The death and life of great American cities, Random House, New York.

Karshenas, M. (1997), Dynamic economies and the critique of urban bias, The Journal of Peasant Studies, 24.

Lefebvre, H. (1974), The production of space, Blackwell, London

M'baye, K. (1972), Le Droit du Developpement comme un Droit de l'Homme, Revue des Droits de l'Homme, 5, 503-534.

McCann, E. (2008), Expertise, truth, and urban policy mobilities: Global circuits of knowledge in the development of Vancouver, Canada's 'four pollar' drug strategy, Environment and Planning A, 40(4), 885-904.

McCann, E. (2011), Urban policy mobilities and global circuits of knowledge: Toward a research agenda, Annals of the Association of Americal Geographers, 101(1), 107-130.

Miraftab, F. (2009), Insurgent planning: Situating radical planning in the Global South, Planning Theory, 8(1), 21-50, SAGE Publications.

Peck, J. and Theodore, N. (2010), Mobilizing policy: Models, methods, and mutations, Geoforum, 41(2), 169-174.

Peck, J. and Theodore, N. (2012), Follow the policy: A distended case approach, Environment and Planning A, 44(1), 21-30.

Sabatier, P.A. and Jenkins-Smith, H. (1988), An advocacy coalition framework of policy change and the role of policy-oriented learning therein, Policy Sciences, 21(2), 129-168.

Schechla, J. (2015), Fractured continuity: Moving from Habitat II to Habitat III, Citiscope commentary, 7 August 2015.

Temenos, C. and McCann, E. (2013), Geographies of policy mobilities, Geography Compass, 7(5), 344-357.

UNGA (1976), A/RES/32/162, International arrangements for international cooperation in the field of human settlements.

UNGA (1986), A/RES/41/120, Declaration on the Right to Development.

UNDESA, Population Division (2015), World Urbanization Prospects: The 2014 Revision, ST/ESA/SER.A/366. 
Ward, K. (2006), 'Policies in motion,' urban management and state restructuring: The trans-local expansion of business improvement districts, International Journal of Urban and Regional Research, 30, 54-75. 
Okitasari: THE NEW URBAN AGENDA, THE INTERNATIONAL CIRCULATION OF URBAN POLICIES AND CHALLENGES OF A HUMANE URBANISM IN THE GLOBAL SOUTH

This page is intentionally left blank 